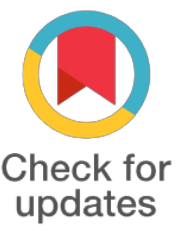

${ }^{*}$ For correspondence:

pvphuc@hcmus.edu.vn

Competing interests: The authors declare that no competing interests exist.

Received: 2017-04-30

Accepted: 2017-05-16

Published: 2017-09-05

Copyright The Author(s) 2017. This article is published with open access by BioMedPress (BMP).

This article is distributed under the terms of the Creative Commons Attribution License (CC-BY 4.0) which permits any use, distribution, and reproduction in any medium, provided the original author(s) and the source are credited.

\section{ETV-2 activated proliferation of endothelial cells and attenuated acute hindlimb ischemia in mice}

\author{
Phuc Van Pham, Ngoc Bich Vu, Hoa Trong Nguyen, Thuy Thi-Thanh Dao, Ha Thi- \\ Ngan Le, Lan Thi Phi, Oanh Thi-Kieu Nguyen, Ngoc Kim Phan
}

Laboratory of Stem Cell Research and Application, University of Science, Vietnam National University HCMC, Ho Chi Minh city, Vietnam

\begin{abstract}
Ischemia is the reduction of blood flow to tissues by injury of blood vessels. Depending on the sites of tissues and grade of ischemia, ischemia can cause many serious complications. This study aimed to evaluate the effects of the E-twenty six (ETS) factor Ets variant 2 (ETV2) gene expression in angiogenesis and the effect of ETV 2 gene therapy in a mouse model of hindlimb ischemia. The role of ETV2 on endothelial cell proliferation was evaluated in vitro. Knockdown of ETV 2 expression was done using short hairpin RNA (shRNA) lentiviral viral particles. The ETV 2 viral vector was injected into the skeletal muscles at the ligated and burned sites of the hindlimb and evaluated for its efficacy as a gene therapy modality for ischemia. Vascular regeneration in mice was indirectly evaluated by changes in mouse survival, necrotic grades of the leg, normal blood oxygen saturation level ( $\left.\mathrm{SpO}_{2}\right)$, and blood flow by trypan blue injection assay. Preliminary data showed that ETV 2 expression played a role in angiogenesis of endothelial cells. ETV 2 overexpression could trigger and stimulate proliferation of skeletal endothelial cells. In vivo knockdown of ETV 2 expression inhibited the auto-recovery of ischemic hindlimb, while overexpression of ETV 2 helped to rescue leg loss and reduce necrosis, significantly improving angiogenesis in hindlimb ischemia. Our findings demonstrate that ETV2 gene therapy is a potentially effective modality for vascular regeneration.
\end{abstract}

\section{Keywords}

ETV-2 Endothelial cells Ischemia Hindlimb ischemia Angiogenesis

\section{Funding}

This research was funded by the Vietnam 532 National Foundation for Science and Technology Development 533 (NAFOSTED) under grant number 106-YS.06-2013.37.

\section{References}

